\title{
An Error Correction Model Analysis of Indonesia's Tourism and International Trade
}

\author{
Tonny Hendratono and Veny Anindya Puspitasari
}

Universitas Bunda Mulia Jakarta

Corresponding author: veny.anindya@gmail.com

\section{ARTICLE INFO}

Received

24 August 2018

Accepted

12 September 2018

Available online

20 September 2018

\begin{abstract}
The tourism sector is the mainstay of Indonesia's foreign exchange contributor. Through its affordability with various other sectors, tourism is considered to be able to influence the country's international trade through the mechanism of exports and imports. This study aims to analyze the influence of tourism on Indonesia's trade balance in the short and long term. The theory of comparative advantage and Heckscher-Ohlin are aimed to answer the purpose of this study. Using the Error Correction Model (ECM), this research shows that tourism has a positive and significant impact on exports and imports in the long and short term. However, in the long term the influence of tourism on imports is greater than that of exports. The opposite thing is happened in the short term.
\end{abstract}

Keywords: tourism, international trade, Error Correction Model

\section{INTRODUCTION}

\section{Background}

Indonesia's economy during 2014 in the second quarter of 2018 shows its optimism. This optimism arises one of them from the economic growth that increased in 2017 compared to the previous year. The World Bank even predicts that Indonesia's economic growth in 2018 will reach $5.2 \%$.

To be able to maintain a stable economy and move towards a better direction; through one of the nine priority agendas for Indonesia that was proclaimed through Nawacita, Indonesia's President and vice president Joko Widodo - Jusuf Kalla (Jokowi JK) government is intensively developing Indonesia from the periphery in order to catch up all this time, one of them is an economic lag. Through the National Medium Term Development Plan (RPJMN) issued by Jokowi - JK which is an extension of the Master Plan for the Acceleration and Expansion of Indonesian Development (MP3I) from the previous government, which is in line with the national development vision set forth in Law No. 17 of 2007 concerning the 2005-2025 National Long Term Development Plan; the Jokowi - JK government wanted to invite all the people to catch up.

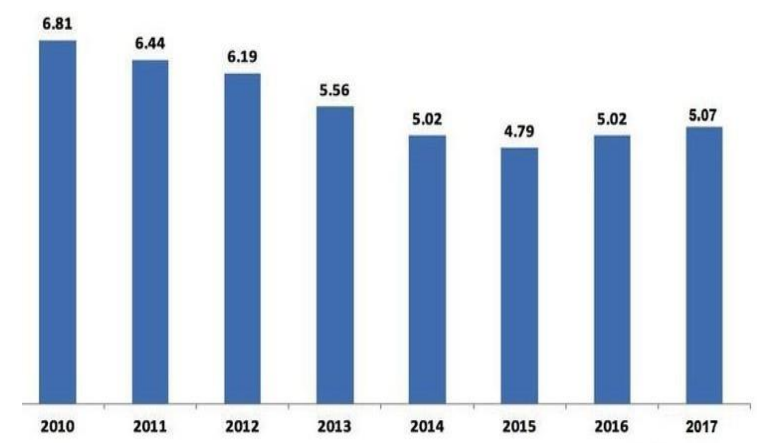

Source: Central Bureau of Statistics, 2018

Figure 1. Indonesian Economic Growth in $2010-2017$ 
Tourism is a sector that contributes significantly to the Indonesian economy. This sector is even targeted to contribute to Gross Domestic Product (GDP) in 2017 at $13 \%$ of national GDP. GDP in the tourism sector occurs through the expenditure of domestic tourists, government tourism budgets, foreign tourist spending, and investment in tourism businesses which include: (1) business tourism attraction; (2) tourism area business; (3) tourist transportation services; (4) travel services; (5) food and beverage services; (6) accommodation provider; (7) organizing entertainment and recreation activities; (8) organizing meetings, incentive trips, conferences and exhibitions; (9) tourism information services; (10) tourism consulting services; (11) guide services; (12) water tourism; and (13) spa.

The tourism sector also plays a strategic role in creating added value for the national economy through its reach to many other sectors such as infrastructure, transportation, and other services. With this role, the tourism sector is considered to be able to contribute greatly to increasing the country's foreign exchange reserves. Therefore, it can be said that the tourism sector is one sector that is able to influence a country's trade balance.

\section{Research Objective}

This study aims to analyze the influence of tourism on Indonesia's trade balance in the short and long term.

\section{LITERATURE REVIEW}

\section{International Trade Theory: Comparative Advantages}

The relevance of international trade theory with the tourism economy has been recognized for a long time. The discussion of tourism relations with international trade in the literature usually refers to two main approaches: (i) the theory of comparative advantage and (ii) the Heckscher-Ohlin (H-O) theory.

The theory of comparative advantage is a theory put forward by David Ricardo. According to him, international trade http://ojs.unud.ac.id/index.php/eot occurs when there are differences in comparative advantage between countries. $\mathrm{He}$ argues that comparative advantage will be achieved if a country is able to produce more goods and services at a lower cost than other countries. In the theory of comparative advantage, a nation can improve its standard of living and income if the country specializes in the production of goods or services that have high productivity and efficiency. This theory is based on assumptions: (1) Labor Theory of Value, namely that the value of an item is determined by the amount of labor used to produce the item, where the value of the goods exchanged is balanced by the amount of labor used to produce it; (2) International trade is seen as an exchange of goods with goods; (3) The costs of transportation and others are not taken into account; (4) Marketing, production run at a fixed cost, this means that the scale of production has no effect; (5) Factors of production are not mobile at all between countries. Therefore, a country will specialize in the production of goods and export them if the country has an advantage and will import goods needed if it has a loss in producing. According to the law of comparative advantage of David Ricardo, even though a country is less efficient than (or has an absolute loss to) other countries in producing both types of commodities produced, there is still a basis for trading that benefits both parties.

In the theory of comparative advantage (comparative advantage) it is stated that the difference in the abundance of relative production factors serves as the main basis for a country to conduct international trade. A country will produce and then export items that have the biggest comparative advantage (the item that can be produced cheaper or more efficiently and more productively) and import goods that have comparative disadvantage (goods that produce higher costs themselves). In the context of tourism, this theory applies to many developing countries with abundant tourism and labor resources such as Indonesia because they have an abundance of factors of production to develop tourism products, means having comparative advantages to export tourism services. 


\section{International Trade Theory: Heckscher- Ohlin}

According to the Heckscher-Ohlin (H-O) theory a country will trade with other countries because the country has comparative advantages. The basis of comparative advantage in H-O theory is: (1) endowment factors, namely ownership of factors of production in a country; and (2) intensity factors, namely the technology used in the production process, whether labor intensity or capital intensity. Each country that conducts trade tends to specialize in the production and export of certain goods because the country has relatively large and cheap production factors to produce it. On the contrary, each country will import certain goods because the country has relatively few production factors and is expensive to produce.

However, it does not mean those countries that do not have superiority in the ownership of production factors cannot trade with other countries. Although a country does not have abundant resources or factors of production in the tourism sector but is able to produce tourism products and services that are attractive so that it is included in the ranks of the main tourist destinations in the world (Khan and Lin, 2002).

Another approach that is often used to see the influence or relationship of trade with tourism is based on the motives of people to travel. According to Spillane (1994), people traveling are driven by the desire to: (1) have pleasure (pleasure tourism); (2) recreation (recreation tourism); (3) sports (sports tourism); (4) cultural tourism (cultural tourism); (5) for conventions (convention tourism); and (6) for trading business or business purposes (business tourism).

The motive that is considered most relevant to trade is a business trip. Because this trip is a professional trip (professional trips) and usually associated with work or position. This business tour is not only carried out by entrepreneurs or industrialists, but also by the visitors of the exhibition. Entrepreneurs / industrialists and exhibition visitors also act as consumers / buyers and sellers for certain products in the countries visited. Therefore, the success of business travel directly will create a flow of exports and / or imports in the next period.

However, tourist visits with other motives can also affect trade. Tours for fun or leisure purposes can identify business opportunities, which can further affect exports and imports in the next period. Tourists can also consume certain types of goods that are not produced in tourist destinations so that the country must import. The implication is that the country is experiencing pressure for import needs. In addition, tourism also shows a shift in consumption from the countries of origin of visitors to tourist destinations. Thus, tourism and trade can show complementary or substitutionary relationships, depending on the goods to be imported or exported, as a representation of international trade (SantanaGallego, Ledesma-Rodríguez and PérezRodríguez, 2011).

\section{RESEARCH METHODS}

\section{Data}

In this study, the data used is the number of foreign tourist arrivals to Indonesia, exports and imports for the period January 2015 to December 2017 which are presented monthly and produce a time series data.

\section{Analysis Method}

Error correction model (ECM Error Correction Model) is a linear regression model that determines the long-term balance between several variables. In the error correction model an adjustment is made so that there is a balance between what is desired and what is happened. Error correction models can be used on variables that are not stationary but cointegrated. The error correction model is used to overcome the problem of nonstationary time series data, smooth regression problems, correct short-term imbalances and to form long-term equilibrium relationships between variables. Because this study uses time series data, the use of the ECM model is carried out through several stages, namely:

(i) Stationary test (unit root test) to prove the stability (normality) pattern of each variable, so that the resulting regression is not spurious (false) so it does not produce 
a wrong interpretation. The testing method used is Phillip Perron Test.

(ii) Integration degree test to find out to what degree a data will be stationary. If the variables included in the equation above have the same degree of integration, then these variables are said to have equilibrium relationships or cointegrated and can be said to have a long-term balance relationship; and

(iii) Develop an ECM regression model to correct short-term imbalances towards long-term equilibrium.

\section{RESULTS AND DISCUSSION}

\section{Phillip-Perron Data Stationary Test (PP)}

This test was carried out using nonparametric statistical methods in explaining the existence of autocorrelation between residuals without including the independent variable of differential inaction. The advantage of using this test is the assumption that there is no form of function for the residual process variables so that the PP test is said to be a nonparametric test. Because it is non-parametric, the PP test can be used in many cases and in large samples, the PP test will show good results.

Table 1. Root Test Unit PP Results

\begin{tabular}{lc}
\hline & Export \\
\hline With Intercept & 0.5480 \\
\hline With Intercept and Trend & 0.8718 \\
\hline $\begin{array}{l}\text { Without Intercept and } \\
\text { Trend }\end{array}$ & 0.7573 \\
\hline
\end{tabular}

Source: Developed in this research

From Table 1 can be seen that in the export variable, all probabilities are above $1 \%$, $5 \%$, or $10 \%$. This means that the root test of the export variable unit is not stationary. The same thing also happens to the import variable where all the probability values exceed $1 \%$, $5 \%$, or $10 \%$ so that they are declared not stationary. Whereas for tourism variables there is one probability value whose value is smaller than $1 \%, 5 \%$, or $10 \%$, that is when tested with intercepts and trends. But in other tests (with intercepts and without intercepts and trends) the probability value is greater than $1 \%, 5 \%$, or $10 \%$ so that it is declared not stationary. Thus it can be concluded that at this stationary stage, all the research variables are not stationary so it needs to do the first stage integration degree testing.

Table 2. Results of First Level Integration Test

\begin{tabular}{lccc}
\hline & Export & Import & Tourism \\
\hline With & 0.0002 & 0.0005 & 0.0002 \\
Intercept & & & \\
\hline With & 0.0005 & 0.0038 & 0.0000 \\
Intercept & & & \\
and & & & \\
Trend & & & \\
\hline $\begin{array}{l}\text { Without } \\
\text { Intercept }\end{array}$ & 0.0000 & 0.0000 & 0.0000 \\
and & & & \\
Trend & & & \\
\hline
\end{tabular}

Source: Developed in this research

The test results shows that the data has met stationary requirements because the probability value is smaller than $1 \%, 5 \%$, or $10 \%$ and all-time series data can be concluded to be integrated at the same degree, namely one or I integration degree (1).

\section{Cointegration Test}

Cointegration test was popularized by Englimpofftanger (1987) (Gujatiki3909).

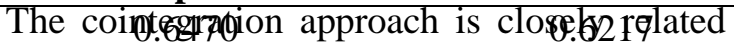
to the tegt.9.98 $2 \mathrm{f}$ the possibility of balance 0.70 dgtionship between 0.999 search variables. The cointegration approach can also be seen as a test of theory and is an important part of the formulation and estimation of a dynamic model (Engle and Granger, 1987). The cointegration test used in this study is the cointegration test developed by Johansen. 
Table 3. Estimation of Export Variable Long Term Equation

\begin{tabular}{ccccc}
\hline $\begin{array}{c}\text { Varia } \\
\text { ble }\end{array}$ & $\begin{array}{c}\text { Coeffici } \\
\text { ent }\end{array}$ & $\begin{array}{c}\text { Std. } \\
\text { Error }\end{array}$ & $\begin{array}{c}\text { t- } \\
\text { Statist } \\
\text { ic }\end{array}$ & $\begin{array}{c}\text { Probabi } \\
\text { lity }\end{array}$ \\
\hline $\mathrm{C}$ & 5838.39 & 2380. & 2.453 & \\
& 2 & 010 & 096 & 0.0207 \\
\hline Touris & 0.01227 & 0.003 & 3.533 & \\
$\mathrm{~m}$ & 0 & 472 & 719 & 0.0014 \\
\hline $\mathrm{R}^{2}$ & 0.30842 & & & \\
& 3 & & & \\
\hline Numb & 30 & & & \\
er of & & & & \\
Obs. & & & & \\
\hline
\end{tabular}

Source: Developed in this research

From Table 3 can be made the following equation: Export $=5838.392+$ 0.012270 Tourism. Besides that, it can be seen that the probability value is 0.0014 . This means that in the long run, the tourism variable significantly affects the export variables at a significance level of $1 \%, 5 \%$, and $10 \%$. The influence of Tourism is able to explain the variation of the export variable movement of 0.308423 , as indicated by the $\mathrm{R} 2$ value. Changes in the independent variable (Tourism) are able to explain the variation of the dependent variable (Export) around $30.84 \%$, while the rest (around $69.15 \%$ ) is explained by other variables outside the model.

Table 4. Estimation of Import Variable Long Term Equation

\begin{tabular}{ccccc}
\hline $\begin{array}{c}\text { Varia } \\
\text { ble }\end{array}$ & $\begin{array}{c}\text { Coeffici } \\
\text { ent }\end{array}$ & $\begin{array}{c}\text { Std. } \\
\text { Error }\end{array}$ & $\begin{array}{c}\text { t- } \\
\text { Statisti } \\
\text { c }\end{array}$ & $\begin{array}{c}\text { Prob } \\
\text { • }\end{array}$ \\
\hline $\mathrm{C}$ & 1399.26 & 2302.9 & 0.6075 & 0.54 \\
& 7 & 67 & 93 & 84 \\
\hline Touris & 0.01730 & 0.0033 & 5.1512 & 0.00 \\
$\mathrm{~m}$ & 8 & 60 & 27 & 00 \\
\hline $\mathrm{R}^{2}$ & 0.48657 & & & \\
& 0 & & & \\
\hline Numbe & 30 & & & \\
r of & & & & \\
Obs. & & & & \\
\hline
\end{tabular}

From Table 4 can be made the following equation: Import $=1399,267+$ 0.017308 Tourism. In addition it can be seen http://ojs.unud.ac.id/index.php/eot that the probability value is 0.0000 . This means that in the long run, the tourism variable significantly influences the import variables at a significance level of $1 \%, 5 \%$, and $10 \%$. The influence of Tourism is able to explain the variation in the movement of the Import variable of 0.486570 , as indicated by the value of R2. Changes in the independent variable (Tourism) are able to explain the variation of the dependent variable (Import) around $48.65 \%$, while the rest (around $51.34 \%$ ) is explained by other variables outside the model.

Table 5. Johansen Cointegration Test Result

\begin{tabular}{|c|c|c|c|c|}
\hline $\begin{array}{l}\text { Hypothes } \\
\text { ized } \\
\text { No. of } \\
\text { CE(s) }\end{array}$ & $\begin{array}{l}\text { Eigenv } \\
\text { alue }\end{array}$ & $\begin{array}{l}\text { Trace } \\
\text { Statisti } \\
\text { c }\end{array}$ & $\begin{array}{l}0.05 \\
\text { Critica } \\
1 \\
\text { Value }\end{array}$ & $\begin{array}{l}\text { Prob. } \\
* *\end{array}$ \\
\hline None $*$ & $\begin{array}{l}0.5841 \\
68\end{array}$ & $\begin{array}{l}38.76 \\
206\end{array}$ & $\begin{array}{l}35.12 \\
090\end{array}$ & $\begin{array}{l}0.01 \\
95\end{array}$ \\
\hline $\begin{array}{l}\text { At most } \\
1 *\end{array}$ & $\begin{array}{l}0.4928 \\
53\end{array}$ & $\begin{array}{l}21.30 \\
716\end{array}$ & $\begin{array}{l}18.40 \\
771\end{array}$ & $\begin{array}{l}0.01 \\
91\end{array}$ \\
\hline $\begin{array}{l}\text { At most } \\
2 *\end{array}$ & $\begin{array}{l}0.3737 \\
14\end{array}$ & $\begin{array}{l}8.375 \\
688\end{array}$ & $\begin{array}{l}3.951 \\
466\end{array}$ & $\begin{array}{l}0.00 \\
40\end{array}$ \\
\hline
\end{tabular}

The trace statistic value $\mathrm{r}=0$ is greater than the critical value with a significance level of $5 \%$, which is 38.76206> 35.12090. This means that the null hypothesis which states that no cointegration is rejected and an alternative hypothesis stating that there is no cointegration cannot be rejected. Based on the econometric analysis above, it can be seen that among the three variables in this study, there is one cointegration at the 5\% significance level. Thus, the results of the cointegration test indicate that between tourism, export and import movements have long-term stability / balance and similarity movements. In other words, in each short-term period, all variables tend to adjust to each other, to achieve long-term equilibrium. 


\section{Error Correction Model (ECM) Test}

After conducting the cointegration test and the results shown by the model explain that the data has a long-term relationship or balance. What about the short term, it is very possible that there is an imbalance or both do not reach balance. The technique for correcting short-term imbalances towards a long-term balance is called the Error Correction Model (ECM), which was introduced by Sargan and popularized by Engle-Granger.

The ECM model is generally a concept of a time-bound econometric model that aims to balance short-term conditions with long-term equilibrium conditions through an adjustment process. Engle \& Granger (1987) argued that if among a number of variables there is cointegration, then a condition called error correction representation is obtained which indicates that what happens to the dependent variable is not only affected by the independent variable but also influenced by the balance of the cointegration relationship. The imbalance of this cointegration relationship is shown by the error correction term value. In addition, ECM econometrics is useful in overcoming the problem of nonstationary time series data and spurious regression problems.

Table 6. ECM Estimation Results of Export Variable

\begin{tabular}{lllll}
\hline Variable & $\begin{array}{l}\text { Coeffici } \\
\text { ent }\end{array}$ & $\begin{array}{l}\text { Std. } \\
\text { Error }\end{array}$ & $\begin{array}{l}\text { t- } \\
\text { Statisti } \\
\text { c }\end{array}$ & $\begin{array}{l}\text { Prob } \\
\cdot\end{array}$ \\
\hline $\mathrm{C}$ & - & & - & \\
& 20.8331 & 272.38 & 0.0724 & 0.94 \\
& 6 & 43 & 05 & 28 \\
\hline D(Touri & 0.00905 & 0.0038 & 2.0907 & 0.04 \\
sm) & 4 & 52 & 85 & 65 \\
\hline ECT1(- & - & & - & \\
$1)$ & 0.19396 & 0.1280 & 1.5142 & 0.14 \\
& 9 & 98 & 27 & 20 \\
\hline $\mathrm{R}^{2}$ & 0.18040 & & & \\
& 1 & & & \\
\hline $\begin{array}{l}\text { Number } \\
\text { of Obs. }\end{array}$ & 29 & & & \\
\hline
\end{tabular}

Table 7. ECM Estimation Results of Import Variable

\begin{tabular}{lllll}
\hline Variable & $\begin{array}{l}\text { Coeffici } \\
\text { ent }\end{array}$ & $\begin{array}{l}\text { Std. } \\
\text { Error }\end{array}$ & $\begin{array}{l}\text { t- } \\
\text { Statisti } \\
\text { c }\end{array}$ & $\begin{array}{l}\text { Prob } \\
\cdot\end{array}$ \\
\hline $\mathrm{C}$ & 24.0298 & 250.74 & 0.0958 & 0.92 \\
& 4 & 53 & 34 & 44 \\
\hline D(Touri & 0.00869 & 0.0036 & 2.0860 & 0.04 \\
sm) & 7 & 42 & 70 & 69 \\
\hline ECT2(- & - & & - & \\
$1)$ & 0.14791 & 0.1258 & 1.1755 & 0.25 \\
& 7 & 30 & 37 & 04 \\
\hline $\mathrm{R}^{2}$ & 0.15360 & & & \\
& 8 & & & \\
\hline $\begin{array}{l}\text { Number } \\
\text { of Obs. }\end{array}$ & 29 & & & \\
\hline
\end{tabular}

From the estimation results in Tables 6 and 7 it can be seen that in the short term variations in the movement of the value of the dependent variable DExport are significantly influenced by the DTourism variable at a significance level (real level) of $5 \%$. Similarly, the influence of DTourism on the DImport variable in the short term is also significant at the significant level of $5 \%$. The lag variable (ECT1 and ECT2) - which represents the error correction term (ECT) - in both equations does not show a significant effect. In general, the ECM model above is able to explain variations in Export and Import together, each at $18.04 \%$ and $15.36 \%$.

The results of ECM regression for short-term equations in Tables 6 and 7 can be summarized in the form of the following equation:

DExport $=-20.83316+0.009054$ DTourism 0.193969 ECT1 (-1)

DImport $=24.02984+0.008697$ DTourism 0.147917 ECT2 (-1)

The regression results in the DExport equation show that the speed of adjustment in this short-term model is 0.193969 . This indicates the variable speed in adjusting its movement towards the long-term trend. With a negative value means that the decrease in the imbalance value of the variables in the model explains the change in 1 export unit (DExport) of 0.193969. In other words, about $19.39 \%$ of the imbalance between the actual export value and the 
desired export value will be eliminated or eliminated in one period (one month). Meanwhile, the regression results in DImport equations show that the variable speed in adjusting the speed of adjustment towards the long-term trend is -0.147917 . With a negative value means that around $14.79 \%$ the imbalance between the actual import value and the desired import value will be eliminated or eliminated in one period (one month).

\section{Discussion}

From the results of a series of tests that included unit root tests, cointegration tests, and ECM tests, the results showed that in the long run the tourism sector had a positive and significant influence on Indonesian international trade. The increase of the tourism sector by $1 \%$ will increase the export value by $1.2 \%$ and the import value will increase by $1.7 \%$. Likewise, if the tourism sector has decreased by $1 \%$, the export value will decrease by $1.2 \%$ and the import value will decrease by $1.7 \%$. But even though the influence is positive and significant, the magnitude of the influence is not too large.

Tourism data used in this study is the number of foreign tourists visiting Indonesia. If it is associated with exports, if the number of foreign tourists visits increases by $1 \%$, it will increase the export value by $1.2 \%$. Indonesia's tourism exports are divided into three main products namely natural tourism, cultural tourism, and man-made tourism (Ministry of Trade, 2015). In 2015, cultural tourism dominated tourism exports by $65 \%$. As an implication, requests for souvenirs that reflect the uniqueness of certain regional cultures such as wayang and angklung are quite high (Ministry of Trade, 2015). When in their home country, foreign tourists still want to feel the regional culture in Indonesia they have visited.

But in 2017 the tourist trend is changing. Marine tourism and other nature dominate the motives of foreign tourists to visit Indonesia (Prodjo, 2017). Many tourism objects in Indonesia offer natural beauty and experience to interact with nature such as diving and mountain climbing. This is supported by the government which will continue to increase the number of visa-free

http://ojs.unud.ac.id/index.php/eot recipient countries and also add tourism facilities. One of the tourism facilities that is the main attraction is cruise ships. In Indonesia there are five ports that can be used as cruise ship embarkation, namely Tanjung Priok Port, Tanjung Perak Harbor, Belawan Port, Makassar Port, and Bali Benoa Harbor. The transition of this tourist trend and coupled with the stability of the Rupiah exchange rate has triggered low tourism exports in the long run.

Low value also occurs in the longterm influence of foreign tourist arrivals on Indonesian imports where every $1 \%$ increase in foreign tourist arrivals to Indonesia will increase imports by $1.7 \%$. But in fact this positive relationship shows a chance of leakage for the State. Leaks occur when requests for international standard equipment used in the tourism industry, imported food and beverages that are not able to be provided by local or domestic communities. Especially in developing countries, international standard food and drinks must be imported from abroad on the grounds that standards are not met, and consequently local products and local communities as producers cannot market their products for the benefit of tourism. The amount of income from the tourism sector is usually also accompanied by the amount of costs that must be spent to import the products that are considered international standards.

Although both have a positive and significant influence, it turns out the influence of foreign tourist arrivals to Indonesia on Indonesian imports in the long run is greater than its exports. This could be because the factors of comparative advantage that affect exports in the long term can quickly experience adjustments such as tourist tastes for the types of tourism that are in demand as well as government intervention in controlling the Rupiah exchange rate. Whereas imports which tend to be more affected by foreign tourist arrivals can occur due to the characteristics of foreign tourists coming to Indonesia. According to the Central Bureau of Statistics (2018), tourists coming from China, Singapore, and Australia are in the top ranks of the countries that visit Indonesia most frequently in 2017. Of the three countries, tourists from Singapore and Australia share the same characteristics namely liking modernity. They really like visiting night clubs 
and enjoying entertainment and drinks that are classified as luxury and imported from abroad (Spillane, 1994; Visitpare, 2017). The intensity of tourist arrivals from Singapore and Australia was allegedly the cause of higher import increases compared to exports in the long run.

In the short term, foreign tourist arrivals to Indonesia affect exports and imports positively and significantly but not up to $1 \%$ where $0.9 \%$ and $0.8 \%$ respectively. This could be due to the nature of their visit which is only a few days so it does not provide a significant economic impact. But in contrast to the long term, in the short term foreign tourist arrivals affect exports more than imports even though they are not too far apart. This could be because in the short term foreign tourists still feel the impression of the tourism they feel on tourist attractions in Indonesia. But in the long run that impression can be lost because many other tourist destinations in the world also offer comparative advantages.

\section{CONCLUSION}

Based on the findings and analysis in the previous section it can be stated that in the long run and short term tourism has a positive and significant influence on the growth of Indonesian exports and imports. In tourism it affects imports more than exports. This is due to the characteristics of foreign tourists visiting Indonesia who like modernity by visiting nightclubs and increasing demand for goods from abroad. Whereas in the short term tourism influences the country's exports in the short term foreign tourists can still feel the impression of the tourism they feel while in Indonesia.

\section{Suggestions for further research}

Based on the conclusions stated earlier, there are several suggestions that can be used as recommendations for the government in formulating tourism policies and international trade, as follows:

1) A small tourism influence on Indonesia's international trade needs to be addressed by integrating government policies to increase the number of foreign tourists visiting Indonesia with international trade policies. In the process, the government

http://ojs.unud.ac.id/index.php/eot needs to synergize several relevant ministries such as the Ministry of Tourism, Ministry of Finance, Ministry of Industry, and Ministry of Trade and nonministerial institutions such as the Creative Economy Agency to jointly enhance the comparative advantage of Indonesian tourism.

2) Regarding the magnitude of the influence of tourism on imports, the government also needs to review the import duty policy especially on beverage products. The high import duty imposed on beverage products, especially alcoholic beverages, is vulnerable to smuggling. Therefore, the government through the Directorate General of Customs and Excise needs to take various anticipatory and safeguard measures such as increasing difficulties so that the security system is not easily penetrated by potential smugglers by carrying out multiple layers of supervision.

\section{REFERENCES}

Central Bureau of Statistics (2018) Laporan Perekonomian Indonesia 2017. Available at: https://www.bps.go.id/publication/2017/ 09/27/96607b0fa1ba5649ce573500/lapo ran-perekonomian-indonesia-2017.html (Accessed: 10 August 2018).

Engle, R. F. and Granger, C. W. J. (1987) 'Cointegration and error correction: representation, estimation, and testing', Econometrica: journal of the Econometric Society. JSTOR, pp. 251276.

Gujarati, D. N. (2009) Basic econometrics. Tata McGraw-Hill Education.

Khan, H. and Lin, C. C. (2002) 'International trade and tourism: Evidence from cointegration and causality tests by using Singapore data', in The 33rd Annual Conference of Travel and Tourism Association (TTRA), pp. 23-26. 
Ministry of Trade (2015) Geliat Ekspor Law No. 17 of 2007 concerning the 20052025 National Long Term Development Plan Pariwisata. Available at: http://djpen.kemendag.go.id/app_fronte nd/admin/docs/publication/9201455003 103.pdf (Accessed: 10 August 2018).

Prodjo, W. (2017) Tren 2017 Masih Wisata Bahari yang 'Instagramable'. Available at: https://travel.kompas.com/read/2017/01/ 04/151400927/tren.2017.masih.wisata.b ahari.yang.instagramable. (Accessed: 10 August 2018).

Santana-Gallego, M., Ledesma-Rodríguez, F. and Pérez-Rodríguez, J. V (2011) 'Tourism and trade in OECD countries. A dynamic heterogeneous panel data analysis', Empirical Economics. Springer, 41(2), p. 533.

Spillane, J. J. (1994) 'Siasat Ekonomi dan Rekayasa Kebudayaan Pariwisata Indonesia'. Yogyakarta (ID): Kanisius.

Visitpare (2017) Memahami Karakter \& Budaya Wisatawan Mancanegara. Available at: https://visitpare.com/senidan-budaya/memahami-karakterbudaya-wisatawan-mancanegara/ (Accessed: 10 August 2018). 